\title{
Social Integration of the Former Transcarpathian Students of the Balassi Institute
}

\author{
Katalin Pallay ${ }^{1}$ \\ Recommended citation: \\ Pallay K. (2020). Social Integration of the Former Transcarpathian Students of the Balassi Institute. Central European \\ Journal of Educational Research, 2(3), 82-89. https://doi.org/10.37441/CEJER/2020/2/3/8533
}

\begin{abstract}
In the present study, we examine the social integration of former Transcarpathian students who participated in the university preparatory training of the Balassi Institute. Social integration plays a major role, both among mobile students settling in the destination country and in the sending country. Despite the fact that Hungarian students from Transcarpathia have the same linguistic and cultural background as their motherland, their integration into Hungarian society is often hampered: migration often involves giving up home connections, and the success of building new ones is unpredictable. Successful adaptation to the social environment of the destination country is not always an automatic mechanism. Our research was conducted using a questionnaire method. In the survey, we sought to answer the question of where the former Transcarpathian students participating in the preparatory training of the Balassi Institute settled after completing their studies and how they managed to integrate into the society of their place of residence. We compare the social integration of people returning to Transcarpathia, settling in Hungary and living abroad. In summary, we would like to present the results of the survey.
\end{abstract}

Keywords: Transcarpathia, social integration, Balassi Institute, permanent establishment;

\section{Introduction}

Migration processes as well as return and permanent settlement in the motherland are greatly influenced by relational capital and social integration. When defining relational capital, we most often rely on Coleman's theory. According to his concept, relational capital is a social institution between persons, the aim of which is to reduce the social costs incurred by individuals in achieving their goals. Social integration means interaction, contact, reinforcement, acceptance and belonging within a community and their ways and tools (Huszti, 2015; Pusztai, 2015). In terms of migration or mobility, we are talking about a sending network if the network plays a role in migration decision-making. If the network facilitates the integration of immigrants, it is a host network (Tilly, 2001). Despite the fact that Hungarian students from Transcarpathia have the same linguistic and cultural background as their motherland, their integration into Hungarian society is often hampered by migration: migration often involves giving up home relationships, and the success of building new relationships is unpredictable. Successful adaptation to the social environment of the destination country is not always an automatic mechanism.

\section{Research design and Methods}

The target group of our research is the former Transcarpathian students of the university preparatory training of the Balassi Institute. Due to the small number of students, we aimed for a complete query. The data collection took place between March and October 2019. During the research, a complex self-administered questionnaire had to be completed online. The former students were searched by using the snowball method. The number of items in the database is $347.59 .01 \%$ of the target group was reached. All of the respondents are from Transcarpathia. We mapped the social embeddedness of former students along where they settled. Based on the domestic and international literature, as well as preliminary empirical research, we formulated as a research question what differences and similarities can be discovered in social integration between returning students and former students settling in Hungary / settling abroad.

\footnotetext{
${ }^{1}$ Ferenc Rakoczi II Transcarpathian Hungarian College of Higher Education, Ukraine, p.katinka16@gmail.com
} 
According to Gödri's research results, we assume that students who have remained in the motherland have a wider network of contacts and a stronger social embeddedness than their returning fellow students.

The obtained data were analyzed using SPSS 22 program.

\section{Results}

As organizational or association membership is one of the indicators of social integration (Gödri, 2010), in our questionnaire research we mapped what groups and organizations former students are members of. Organizational and association membership can function as a factor promoting integration (Angelusz-Tardos 1998). Respondents are primarily members of religious communities $(36.9 \%)$ or leisure clubs $(16.4 \%)$. The lowest proportion of former students (6.9\%) joined art groups and fan circles (4.3\%). The distributions are illustrated in the figure below.

Figure 1. Participation in organizational membership (\%; $\mathrm{N}=347)$

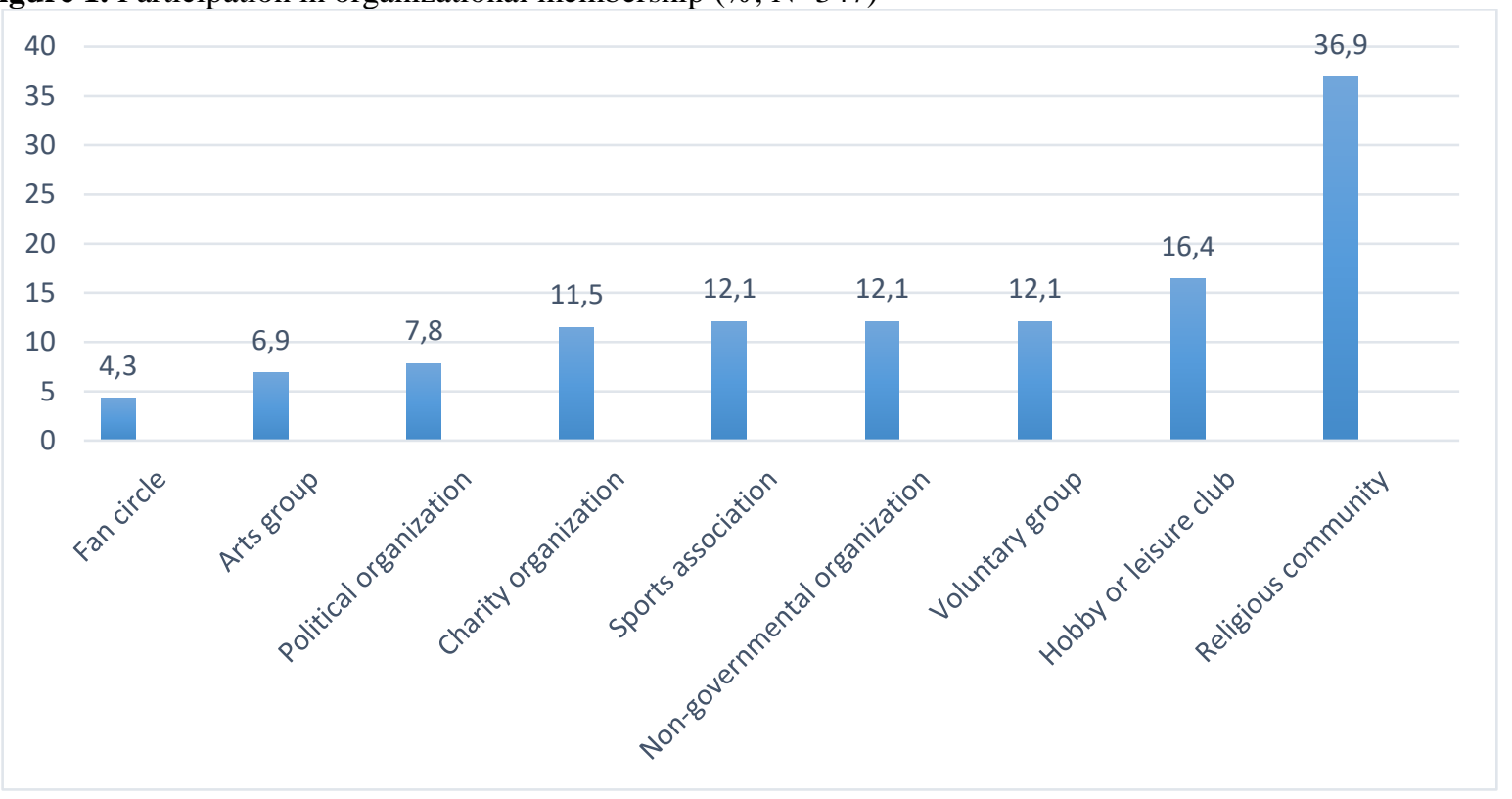

(Source: own editing)

We examined the relationship between organizational membership and final settlement using a chi-square test. A significant relationship can be detected in five cases. $61.8 \%$ of those returning to Transcarpathia are members of some religious community (Adj.Resid. =4.7). A significant proportion of those living in Hungary and abroad (Hungary - 67.3\%, abroad 88.0\%) (Adj.Resid.=2.7) do not form membership in religious communities. Gereben's (1999) research findings highlight that the minority situation values the importance of religiosity and religious practice, as it is of great importance in the preservation of individual and group identity. This finding is also supported by our research results, it is clear that the proportion of members of the Hungarian intellectual living in Transcarpathia, in our case in Transcarpathia, is significantly higher than in the motherland or abroad.

In the case of those returning to their homeland (14.7\%), the proportion of those who are members of an art group is over-represented (Adj.Resid. = 2.8). A significant proportion of former students settling in Hungary $(95.2 \%)$ and the vast majority of those living abroad (92.2\%) are not members of any art group in their place of residence. Presumably, this is due to the fact that the preservation and transmission of culture plays a particularly important role for those living in minority situations, as all this protects them from the danger of integration into society (Gereben, 1999).

In the case of former students returning to Transcarpathia, the proportion (25.0\%) of those who are members of some political organization or party is strongly over-represented (Adj.Resid.=5.9). A significant proportion of those settling in the mainland $(96.0 \%)$ (Adj.Resid. $=4.4$ ) are not members of a political organization. None of those living abroad are members of a political party or organization. A similar trend can be observed for NGOs and charities. Former students who have returned home to Transcarpathia have a much higher proportion (25.0\%) of members of non-governmental organizations than their former fellow students living in Hungary $(9.6 \%)$ or 
abroad (4.0\%). Among those returning to their homeland, the proportion (22.1\%) of those who are members of some kind of charity is over-represented (Adj.Resid. $=3.0$ ). A much smaller proportion (8.4\%) of those living in Hungary are members of these institutions of Hungarian society, among them the proportion of those who are not members of a charitable association is over-represented (Adj.Resid. $=3.1$ ). $16.0 \%$ of those living abroad are members of some kind of charity. Due to the minority situation, Hungarians in Transcarpathia are paying close attention to the political situation in their homeland. Behind this is the fact that they are forced to face the disadvantages they face every day. These include the reduction of mother tongue rights, both in public administration and in education. The issue of dual citizenship and the establishment of the Beregszász-based Hungarian district is also actively concerned with Transcarpathian public life (Kántor, 2013). The Transcarpathian Hungarians living in a minority position strive to preserve their mother tongue and political rights, which results in greater political and social activity. In contrast, students who have settled in the home country do not face such difficulties as they are given the opportunity to be educated in the mother tongue and to assert other interests. The results reflect the fact that, after their studies in Hungary, those settling abroad are the least connected to the organizations and associations of the host society. Our results support the conclusions of Angelusz - Tardos (1998) that in foreign countries, organizational membership is an important element in building networks, but settlers rarely join the organizations and associations of society there. The distributions are illustrated in the table below:

Table 1. Relationship between organizational membership and permanent establishment (\%). N=347

\begin{tabular}{|c|c|c|c|c|c|c|}
\hline \multicolumn{2}{|l|}{ Membership } & $\begin{array}{l}\text { Transcarpa } \\
\text { thia }\end{array}$ & Hungary & Abroad & $\begin{array}{l}\text { Chi- } \\
\text { square }\end{array}$ & Sig. \\
\hline \multirow{2}{*}{$\begin{array}{l}\text { Religious } \\
\text { communities }\end{array}$} & yes & $\underline{61,8}$ & 32,7 & 12,0 & \multirow[t]{2}{*}{26,637} & \multirow[t]{2}{*}{0,000} \\
\hline & no & 38,2 & $\underline{67,3}$ & $\underline{88,0}$ & & \\
\hline \multirow[t]{2}{*}{ Art group } & yes & $\underline{14,7}$ & $\overline{4,8}$ & 8,0 & \multirow[t]{2}{*}{8,164} & \multirow[t]{2}{*}{0,017} \\
\hline & no & 85,3 & 95,2 & $\underline{92,0}$ & & \\
\hline \multirow{2}{*}{$\begin{array}{l}\text { Political } \\
\text { organization, party }\end{array}$} & yes & $\underline{25,0}$ & 4,0 & 0,0 & \multirow[t]{2}{*}{34,969} & \multirow[t]{2}{*}{0,000} \\
\hline & no & 75,0 & $\underline{\underline{96,0}}$ & 100,0 & & \\
\hline \multirow{2}{*}{$\begin{array}{l}\text { Non-governmental } \\
\text { organization }\end{array}$} & yes & $\underline{25,0}$ & 9,6 & 4,0 & \multirow[t]{2}{*}{13,592} & \multirow[t]{2}{*}{0,001} \\
\hline & no & 75,0 & $\underline{90,4}$ & 96,0 & & \\
\hline \multirow{2}{*}{$\begin{array}{l}\text { Charitable } \\
\text { organization }\end{array}$} & yes & $\underline{22,1}$ & 8,4 & 16,0 & \multirow[t]{2}{*}{10,263} & \multirow[t]{2}{*}{0,006} \\
\hline & no & 77,9 & 91,6 & 84,0 & & \\
\hline
\end{tabular}

* For values underlined, the absolute value of adjusted reziduals is greater than two

For permanent residency membership measured by nine variables, we created a new variable, an index with a minimum value of zero if someone is not a member of any organization or association, with a maximum value of seven, as there are no people in our database who are members of all nine organizations. A significant part of the respondents (43.8\%) are not members of any professional, social organization, club or association. $56.2 \%$ of the respondents reported having some kind of membership. A significant difference can be found along social integration and final settlement $(\mathrm{p}=0.000)$. Former students returning to Transcarpathia have the highest integration index, they are members of two organizations on average. On average, those settling in Hungary are members of an organization or association. On average, people living abroad are members of less than one organization. Previous research (Angelusz - Tardos, 1998; Gödri, 2005) confirms that immigrants are less attached to organizations or associations in the host society. This statement is also true for former students from Transcarpathia: as immigrants abroad, they are much less attached to organizations and associations than as returnees in their homeland. Presumably, this is also due to the fact that the traditional values are present among Hungarians abroad, including in Transcarpathia, in which ecclesiastical organizations play a key role (Szarvas, 2014). In addition, organizational mobilization has intensified in Transcarpathia in recent years, one of the aims of which is to defend against language disenfranchisement.

Personal relationships are a type of social capital. In our research, we mapped who the former students are in close contact with. The vast majority of respondents $(79.4 \%)$ have the closest relationship with their families. $28.8 \%$ have the most contact with friends at home, $22.4 \%$ with colleagues at work, and $19.3 \%$ with former university classmates and friends. They have the least contact with groupmates and friends studying together at the Balassi Institute, but $40.2 \%$ still have close contact with them. The distributions are illustrated in the figure below: 
Figure 2. Contact features $(\mathrm{N}=347)$

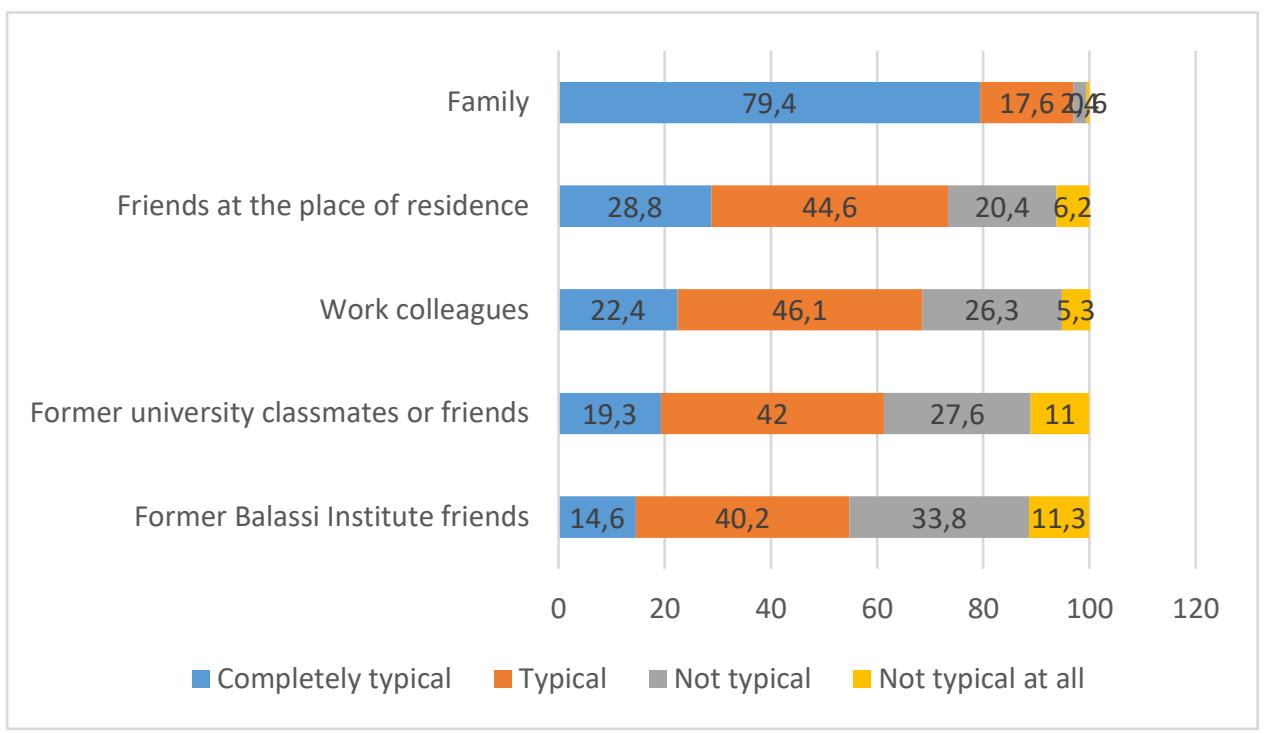

(Source: own editing)

We examined the correlation of the final settlement with the close relationship characteristics by chi-square test, but in this case no significant correlation could be detected.

Social interactions provide a picture of the subject's social environment. In order to map the social environment, we asked whether there were individuals among the respondents who could be approached in different life situations. As social integration and networking play an important role in the design and process of mobility and final settlement, we assessed where these relationships are located.

47.3\% of the respondents answered that the person they spend their free time with lives in Hungary. $25.4 \%$ also have such a relationship in Hungary and Transcarpathia. $44.7 \%$ of the former students answered that they have a friend in Hungary with whom they can talk about scientific issues. $40.8 \%$ have friends in the mainland with whom they used to play sports. The proportion of those who do not have a person in their lives with whom they play sports is relatively high (37.2\%). 39.8\% of them live in Hungary with friends who can talk about reading, culture and public issues. $38.6 \%$ have such a connection in Hungary and Transcarpathia. $41 \%$ of responding former students also have friends in their home country and homeland with whom they are studying or would study. Also, $41 \%$ of people in both countries have someone in their life with whom they can discuss their privacy issues. Plans for the future are discussed in the largest proportion (40.1\%) with friends in both countries. Presumably, they are also considering the chances of returning home and permanent emigration. They talk about art the most $(31.2 \%)$ with friends living in Hungary. $41.7 \%$ said they live in both places with a friend who visits them or contacts them by phone in case of illness. Transcarpathia and other foreign countries have the lowest share of social support. The distributions are illustrated in the figure below. 
Figure 3. Distribution of social support $(\mathrm{N}=347)$

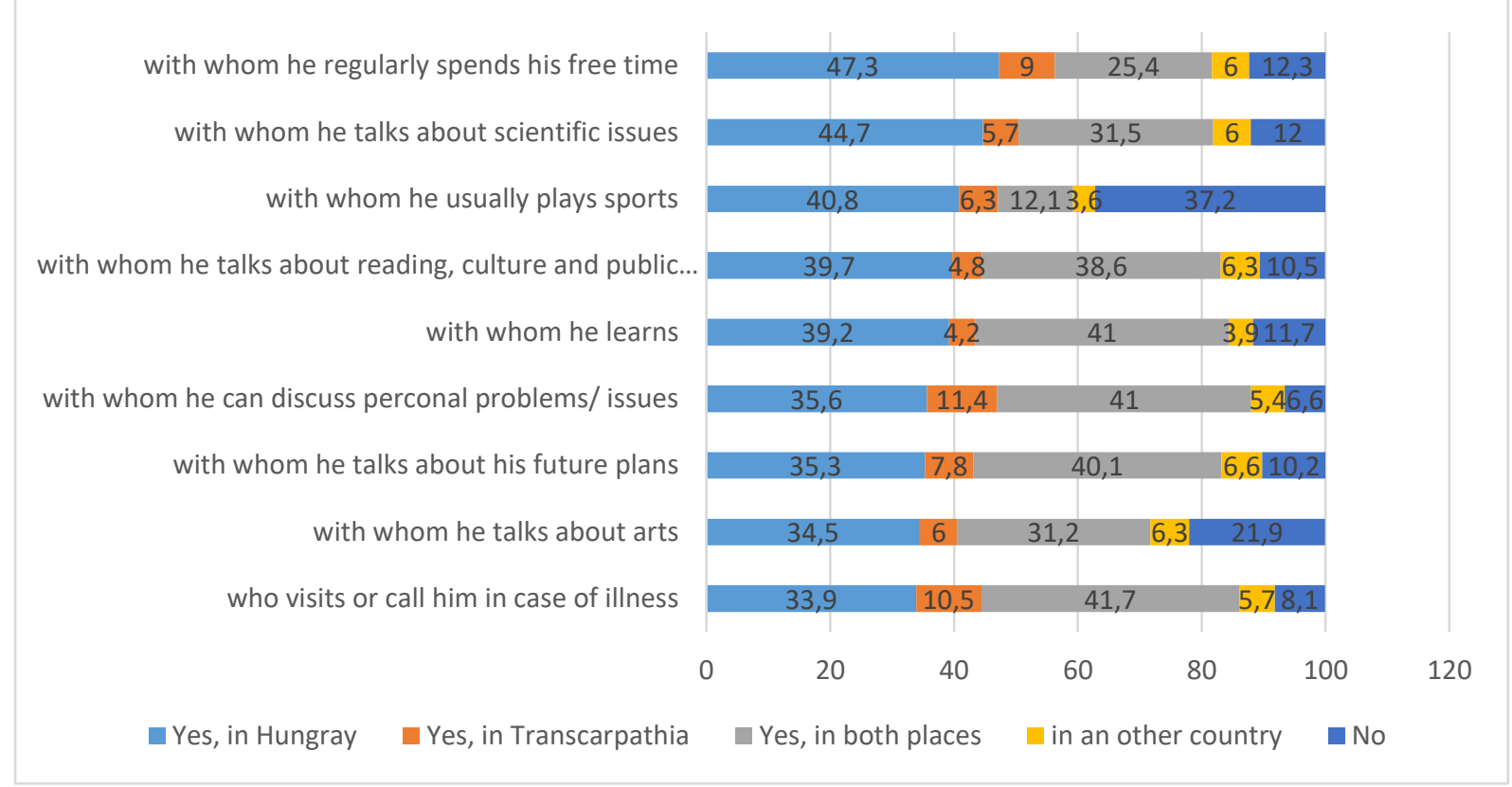

Source: own editing

Social support is one of the indicators of successful social integration (Gödri - Tóth, 2005). In light of this, we examined the relationship between final settlement and social support along several dimensions using a chi-square test. In all cases, a significant relationship can be detected. If we take into consideration the relationship in which they can discuss their privacy problems, it can be said that the proportion of those returning to Transcarpathia, those who cultivate such a relationship in their homeland, is strongly over-represented (Adj.Resid. $=4.7)(28.1 \%$ ), and is overshadowing the proportion (Adj.Resid. = 4.7) $(15.1 \%)$ of those who do not have such a strong bond. Among those living in Hungary, the proportion (44.5\%) of those who have a friend in the motherland with whom they can discuss their privacy problems is over-represented (Adj.Resid. = 5.6). 37.5\% (Adj.Resid. = 7.2) of former students settling abroad have such a relationship abroad. People living in Transcarpathia are most likely (34.4\%) to have friends in their homeland with whom they regularly spend their free time, but in their case the proportion $(25.0 \%)$ of those who do not have such a close relationship is also over-represented. Those settling in Hungary have the most (59.6\%) in Hungary, and those living abroad the most (58.3\%) form this type of relationship with foreigners. The same trend can be observed for other types of close relationships, such as: with whom you discuss plans for the future or who you visit in case of illness, or perhaps contact by phone. If we take into consideration professional relations (e.g. with whom he talks about scientific issues, with whom he talks about readings, culture, art), it is clear that those returning to their homeland have such a connection mostly in Transcarpathia, but the proportion of those in both places (Transcarpathia and Hungary) cultivate such a relationship. The distributions are illustrated in the table below: 
Table 2. Relationship between social support and permanent establishment (\%). N=347

\begin{tabular}{|c|c|c|c|c|c|c|}
\hline & & Transcarpathia & Hungary & Abroad & $\begin{array}{l}\text { Chi- } \\
\text { square }\end{array}$ & Sig. \\
\hline \multirow[t]{5}{*}{$\begin{array}{l}\text { With whom he talks } \\
\text { about private problems }\end{array}$} & $\begin{array}{l}\text { Relationship in } \\
\text { Hungary }\end{array}$ & 10,9 & $\underline{44,5}$ & 12,5 & \multirow[t]{5}{*}{100,0} & \multirow[t]{5}{*}{0,000} \\
\hline & $\begin{array}{l}\text { Relationship in } \\
\text { Transcarpathia }\end{array}$ & $\underline{28,1}$ & 7,3 & 8,3 & & \\
\hline & In both places & 45,3 & 40,0 & 37,5 & & \\
\hline & In another country & 0,0 & 3,7 & $\underline{37,5}$ & & \\
\hline & No relationship & $\underline{15,6}$ & 4,5 & 4,2 & & \\
\hline \multirow{5}{*}{$\begin{array}{l}\text { With whom he } \\
\text { regularly spends his } \\
\text { free time }\end{array}$} & $\begin{array}{l}\text { Relationship in } \\
\text { Hungary }\end{array}$ & 14,1 & $\underline{59,6}$ & 12,5 & \multirow[t]{5}{*}{215,0} & \multirow[t]{5}{*}{0,000} \\
\hline & $\begin{array}{l}\text { Relationship in } \\
\text { Transcarpathia }\end{array}$ & $\underline{34,4}$ & 3,3 & 0,0 & & \\
\hline & In both places & 26,6 & 24,9 & 25,0 & & \\
\hline & In another country & 0,0 & 2,4 & $\underline{58,3}$ & & \\
\hline & No relationship & $\underline{25,0}$ & 9,8 & 4,2 & & \\
\hline \multirow[t]{5}{*}{$\begin{array}{l}\text { With whom he talks } \\
\text { about his future plans }\end{array}$} & $\begin{array}{l}\text { Relationship in } \\
\text { Hungary }\end{array}$ & 9,4 & $\underline{45,3}$ & 4,2 & \multirow[t]{5}{*}{127,5} & \multirow[t]{5}{*}{0,000} \\
\hline & $\begin{array}{l}\text { Relationship in } \\
\text { Transcarpathia }\end{array}$ & $\underline{25,0}$ & 4,1 & 0,0 & & \\
\hline & In both places & 42,2 & 39,2 & 41,7 & & \\
\hline & In another country & 1,6 & 4,1 & $\underline{45,8}$ & & \\
\hline & No relationship & $\underline{21,9}$ & 7,3 & 8,3 & & \\
\hline \multirow[t]{5}{*}{$\begin{array}{l}\text { Who visits or calls him } \\
\text { in case of illness }\end{array}$} & $\begin{array}{l}\text { Relationship in } \\
\text { Hungary }\end{array}$ & 7,8 & $\underline{43,4}$ & 8,3 & \multirow[t]{5}{*}{179,1} & \multirow[t]{5}{*}{0,000} \\
\hline & $\begin{array}{l}\text { Relationship in } \\
\text { Transcarpathia }\end{array}$ & $\underline{39,1}$ & 3,7 & 4,2 & & \\
\hline & In both places & 39,1 & 43,4 & 29,2 & & \\
\hline & In another country & 0,0 & 2,9 & $\underline{50,0}$ & & \\
\hline & No relationship & $\underline{14,1}$ & 6,6 & $\overline{8,3}$ & & \\
\hline \multirow{5}{*}{$\begin{array}{l}\text { With whom he talks } \\
\text { about scientific } \\
\text { questions }\end{array}$} & $\begin{array}{l}\text { Relationship in } \\
\text { Hungary }\end{array}$ & $\overline{12,5}$ & $\underline{56,6}$ & 12,5 & \multirow[t]{5}{*}{129,9} & \multirow[t]{5}{*}{0,000} \\
\hline & $\begin{array}{l}\text { Relationship in } \\
\text { Transcarpathia }\end{array}$ & $\underline{20,3}$ & 2,0 & 4,2 & & \\
\hline & In both places & $\underline{54,7}$ & 24,6 & 37,5 & & \\
\hline & In another country & 0,0 & 4,1 & $\underline{41,7}$ & & \\
\hline & No relationship & 12,5 & 12,7 & 4,2 & & \\
\hline \multirow{5}{*}{$\begin{array}{l}\text { With whom he talks } \\
\text { about reading, culture } \\
\text { or public questions }\end{array}$} & $\begin{array}{l}\text { Relationship in } \\
\text { Hungary }\end{array}$ & 14,1 & $\underline{50,2}$ & 4,2 & \multirow[t]{5}{*}{111,3} & \multirow[t]{5}{*}{0,000} \\
\hline & $\begin{array}{l}\text { Relationship in } \\
\text { Transcarpathia }\end{array}$ & $\underline{17,2}$ & 1,6 & 4,2 & & \\
\hline & In both places & $\underline{56,2}$ & 34,3 & 33,3 & & \\
\hline & In another country & 0,0 & 4,5 & 41,7 & & \\
\hline & No relationship & 12,5 & 9,4 & 16,7 & & \\
\hline \multirow[t]{5}{*}{$\begin{array}{l}\text { With whom he talks } \\
\text { about arts }\end{array}$} & $\begin{array}{l}\text { Relationship in } \\
\text { Hungary }\end{array}$ & 9,4 & $\underline{44,7}$ & 0,0 & \multirow[t]{5}{*}{119,4} & \multirow[t]{5}{*}{0,000} \\
\hline & $\begin{array}{l}\text { Relationship in } \\
\text { Transcarpathia }\end{array}$ & $\underline{18,8}$ & 2,9 & 4,2 & & \\
\hline & In both places & $\underline{42,2}$ & 28,7 & 25,0 & & \\
\hline & In another country & 0,0 & 4,2 & $\underline{45,8}$ & & \\
\hline & No relationship & 29,7 & 19,7 & 25,0 & & \\
\hline \multirow[t]{4}{*}{$\begin{array}{l}\text { With whom he learns } \\
\text { or learnt }\end{array}$} & $\begin{array}{l}\text { Relationship in } \\
\text { Hungary }\end{array}$ & 20,3 & $\underline{46,9}$ & 12,5 & \multirow[t]{4}{*}{79,9} & \multirow[t]{4}{*}{0,000} \\
\hline & $\begin{array}{l}\text { Relationship in } \\
\text { Transcarpathia }\end{array}$ & $\underline{14,1}$ & 2,0 & 0,0 & & \\
\hline & In both places & 46,9 & 38,8 & 45,8 & & \\
\hline & In another country & 0,0 & 2,4 & $\underline{29,2}$ & & \\
\hline
\end{tabular}




\begin{tabular}{|c|c|c|c|c|c|c|}
\hline & No relationship & 18,8 & 9,8 & 12,5 & & \\
\hline \multirow[t]{5}{*}{$\begin{array}{l}\text { With whom he plays } \\
\text { sports }\end{array}$} & $\begin{array}{l}\text { Relationship in } \\
\text { Hungary }\end{array}$ & 11,1 & $\underline{52,3}$ & 4,2 & \multirow[t]{5}{*}{161,7} & \multirow[t]{5}{*}{0,000} \\
\hline & $\begin{array}{l}\text { Relationship in } \\
\text { Transcarpathia }\end{array}$ & 25,4 & 1,2 & 8,3 & & \\
\hline & In both places & 17,5 & 9,9 & 16,7 & & \\
\hline & In another country & 0,0 & 1,2 & $\underline{37,5}$ & & \\
\hline & No relationship & 46,0 & 35,4 & 33,3 & & \\
\hline
\end{tabular}

* For values underlined, the absolute value of adjusted residuals is greater than two

Based on our results, it is clear that the Transcarpathian students who stayed in Hungary managed to integrate into Hungarian society. For each type of relationship, the proportion of those living in Hungary is overrepresented. Students who stayed in the home country are less likely to cultivate contact with the community in their home country.

Among the students who returned to Transcarpathia after completing their studies, it can be shown in several cases that the proportion of those who do not have various strong ties is overrepresented. Although they had established professional relations in their homeland, they had not broken off such relations in the motherland either. Based on the research results of Szentannai (2001), he points out that returning home cannot be considered final in many significant cases. Many so-called "floating lifestyle" in which returning students maintain their professional and personal contacts in the motherland, ready to choose to migrate to Hungary if necessary (Szentannai, 2001; Feischmidt - Zakariás, 2010). Presumably, the use of the "floating lifestyle" can also be demonstrated in the case of the students we examined. Former students returning to Transcarpathia do not develop foreign relations in almost any respect.

\section{Summary}

Our results reflect that our hypothesis, that "students who remain in the home country have a wider network of contacts and a stronger social embeddedness than their returning fellow students," was partially confirmed. The first part of our hypothesis, according to which former students who stayed in Hungary have a wider network of contacts, was fully confirmed. The research results of Gödri-Tóth (2005) show that immigrants belonging to the younger generation may already have family and friendship relations in the host society. Fawcett (1989) highlights that these strong bonds motivate a person considering the chances of migration to migratory processes. In relations that encourage migration, it is important to take into consideration the positive migration model that lies ahead. In many cases, immigrants in the same situation form a close network. Presumably, because of the existing relationships, the same language use and the common cultural values the former students living in the motherland have a wider network of contacts.

Organizational membership is an important indicator of integration into civil society (Gödri, 2005). Along this line, the second part of our hypothesis, according to which the former students who stayed in Hungary have a stronger social embeddedness, has not been proven. Despite the fact that the mentioned group has a larger network of contacts, those returning to Transcarpathia are more active in terms of organizational membership.

\section{References}

Angelusz, R., \& Tardos, R. (1998). A kapcsolathálózati erőforrások átrendeződésének tendenciái a kilencvenes években. (Trends in the Rearrangement of Network Resources in the 1990s). In: Kolosi, T., \& Tóth, I. Gy., \& Vukovich, Gy. (szerk.), Társadalmi Riport. (Social Report). Budapest, TÁRKI. (pp.237-256).

Fawcett, J. T. (1989). Special Silver Anniversary Issue: International Migration an Assessment for the 90's . In: The International Migration Review.(3.pp.671-680).

Feischmidt, M., \& Zakariás I. (2010). Migráció és etnicitás. A mobilitás formái és politikái nemzeti és transznacionális térben. (Migration and Ethnicity. Forms and Policies of Mobility in the National and Transnational Space.) In: Feischmidt, M. (szerk.), Etnicitás. Különbségteremtö társadalom. Gondolat, MTA Kisebbségkutató Intézet, Budapest. (pp.152-169).

Gereben, F. (1999). Identitás, kultúra, kisebbség. Felmérés a közép-európai magyar népesség körében. (Identity, Culture, Minority. Survey of the Hungarian Population in Central Europe.) Budapest, MTA Kisebbségkutató Mühely, Osiris Kiadó. 
Gödri, I. (2005). A bevándorlók migrációs céljai, motivációi és ezek makro- és mikrostrukturális háttere. (Immigrant Migration Goals, Motivations and their Macro- and Microstructural Background.) In: Gödri, I., \& Tóth, P. P. (szerk.), Bevándorlás és beilleszkedés a szomszédos országokból. Magyarországra irányuló bevándorlás az ezredfordulón. Budapest, KSH Népességtudományi Kutatóintézet. (pp.69-129).

Gödri, I. (2010). Bevándorlás és etnicitás - összefüggések nyomában. In: Hárs, Á., \& Tóth, J. (szerk.), Változó migráció - változó környezet. Budapest, MTA Etnikai-nemzeti Kisebbségkutató Intézete. (pp.87-124).

Huszti, É. (2015). Mondd meg, kikkel töltöd az idődet, s megmondom, ki vagy. A társas támogatást nyújtó személyes kapcsolati háló néhány jellemzöje és müködése a Nyíregyházi járásban. In: ACTA Medicinae et Sociolgica. (6. pp. 121-144).

Kántor, Z. (2013). Nemzetpolitikai alapismeretek. (Basic Knowledge of National Politics). Budapest. Nemzeti Közszolgálati és Tankönyv Kiadó.

Pusztai, G. (2015). Tőkeelméletek az oktatáskutatásban. (Capital Theories of Educational Research). In: Varga, A. (Szerk.). A nevelésszociológia alapjai. Pécs, Pécsi Tudományegyetem Bölcsészettudományi Kar Neveléstudományi Intézet - Romológiai és Nevelésszociológiai Tanszék - Wlislocki Henrik Szakkollégium. (pp. 137-160).

Szarvas, H. (2014). Külhoni magyar ifjúsági helyzet(ek). In: Székely, L. (szerk.), Magyar identitás határon innen és túl. Új Ifjúsági Szemle Alapítvány.

Szentannai, Á. (2001). A Magyarországon tanult fiatalok karrierkövetése. (Career Tracking of Young People who have studies in Hungary). In: Regio. (4. pp.113-131).

Tilly, C. (2001). Áthelyezödött hálózatok. (Relocated Networks). In: Sik, E. (Szerk.), A migráció szociológiája. Budapest. Szociális és Családügyi Minisztérium.

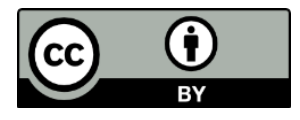

(C) 2020 by the authors. Submitted for possible open access publication under the terms and conditions of the Creative Commons Attribution (CC BY) license (http://creativecommons.org/licenses/by/4.0/). 